\title{
Determining Whether Geographic Origin and Potato Genotypes Shape the Population Structure of Phytophthora infestans in the Central Region of Colombia
}

\author{
Sandra Catalina Chaves, María Camila Rodríguez, María Fernanda Mideros, \\ Florencia Lucca, Carlos E. Nústez, and Silvia Restrepo ${ }^{\dagger}$
}

First, second, third, and sixth authors: Departmento de Ciencias Biológicas, Universidad de los Andes, Bogotá, Colombia; fourth author: Instituto Nacional de Tecnología Agropecuaria, Estación Experimental Agropecuaria Balcarce, República Argentina; and fifth author: Departmento de Agronomía, Facultad de Ciencias Agrarias, Universidad Nacional de Colombia, Bogotá, Colombia.

Accepted for publication 28 July 2018.

\begin{abstract}
Pathogen variation plays an important role in the dynamics of infectious diseases. In this study, the genetic variation of 279 Phytophthora infestans isolates was assessed using a combination of 12 microsatellite simple-sequence repeat markers. Isolates were collected from 11 different potato cultivars in 11 different geographic localities of the central region of Colombia. The objective of this study was to determine whether populations were differentiated by host genotype or geographic origin. Within a single clonal lineage, EC-1, 76 genotypes were detected. An analysis of molecular variance attributed most of the variation to differences within host genotypes rather than among the host genotypes, suggesting that host cultivars do not structure the populations of the pathogen. Furthermore, the lack of a genetic population structure according to the host cultivar was confirmed by all of the analyses, including the Bayesian clustering analysis and the minimum spanning

network that used the Bruvo genetic distance, which suggested that there are no significant barriers to gene flow for $P$. infestans among potato cultivars. According to the geographic origin, the populations of $P$. infestans were also not structured, and most of the variation among the isolates was attributed to differences within localities. Only some but not all localities in the north and west of the central region of Colombia showed some genetic differentiation from the other regions. The absence of sexual reproduction of this pathogen in Colombia was also demonstrated. Important insights are discussed regarding the genetic population dynamics of the $P$. infestans populations of the central region of Colombia that were provided by the results. In Colombia, there is a high genetic variation within the EC-1 clonal lineage with closely related genotypes, none dominant, that coexist in a wide geographic area and on several potato cultivars.
\end{abstract}

Knowledge of the population genetic variation within and among populations is crucial for understanding the main outcomes of the evolutionary processes of pathogens (Hartl and Clark 1997; Hedrick 1985). Population structure and gene flow are commonly used to infer the demographic history of plant pathogens and to determine their potential to generate new variation (McDonald 1997). In agricultural systems, population dynamics play a key role in the ability of the pathogen to rapidly respond to different selection pressures and define the ability of the pathogen to disperse among plant systems (McDonald and Linde 2002; Zhang et al. 2009). The distribution of this genetic diversity and the population structure provide useful insights into the processes driving rapid pathogen evolution and provide strong approaches for designing more efficient and durable disease management strategies (MacDonald 2004; Zhan et al. 2014).

Fungal and oomycete plant pathogens have received special attention in studies of population genetics (Stukenbrock and

†Corresponding author: Silvia Restrepo; E-mail: srestrep@uniandes.edu.co

Funding: This work was supported by the "Convenio Especial de Cooperación Derivado 2. Corredor Tecnológico Agroindustrial-CTA", with the financial support of Sistema General de Regalías, la Secretaría de Ciencia y Tecnología del Departamento de Cundinamarca, la Secretaria Distrital de Desarrollo Económico de Bogotá D.C., Universidad Nacional de Colombia, and CORPOICA.

S. C. Chaves and M. C. Rodríguez are co-first authors of this work.

*The $\boldsymbol{e}$-Xtra logo stands for "electronic extra" and indicates that two supplementary figures and seven supplementary tables are published online.

(C) 2019 The American Phytopathological Society
McDonald 2009). For these species, genetic structure is strongly influenced by the short- and long-term establishment of host interactions, genetic drift, mutations, migrations, and the mode of reproduction (McDonald and Linde 2002; Milgroom et al. 2014; Seidl and Thomma 2014). Molecular markers provide important information regarding genetic and population diversity, and different types of markers have been used to understand the population genetics of several plant pathogens (Drenth et al. 1994; Fry et al. 1991; Lees et al. 2006; Li et al. 2010; Li et al. 2012). Moreover, the recent accessibility to simple-sequence repeat (SSR) markers has helped to provide useful information regarding the levels of genetic diversity and the population structure, which could not be detected by other markers (Cooke et al. 2012; Lees et al. 2009; Li et al. 2013). Therefore, these microsatellites have been widely used to assess the genetic variability and evaluate the population genetic structure of several plant pathogen species (Moges et al. 2016; Njambere et al. 2010; Simpson et al. 2013).

Late blight caused by the plant pathogen Phytophthora infestans (Mont.) de Bary is globally the most devastating disease that affects potato (Fry 2008; Grünwald and Flier 2005). The species is distributed worldwide, and it causes a destructive plant disease that affects potato and many other Solanaceae crops (Fry 2008). Currently, the species most commonly infects Solanum tuberosum, the main type of commercial potato that is grown around the world. Nonetheless, it also infects a wide range of both commercial crops and nondomesticated species within the Solanaceae family (Adler et al. 2002, 2004; Forbes et al. 2011; Oliva et al. 2010; Vargas et al. 2009). Furthermore, despite the intensive effort to control the disease in potato and tomato crops, to date, this pathogen remains a 
major threat to crop production (Fry 2008). Nearly $\$ 5$ billion is invested in the control of this pathogen, and up to $\$ 6.2$ billion per year is associated with production losses of these crops (Haverkort et al. 2008; Visser 2008).

Population genetic studies on this pathogen have focused on the genetic variation and population structure of a wide range of isolates worldwide (Cárdenas et al. 2011; Lees et al. 2009; Li et al. 2012). On potato crops, $P$. infestans populations of the 19th and 20th centuries were dominated by a single clonal lineage, US-1, that was then replaced by HERB-1 outside of Mexico (Yoshida et al. 2013). More recently, one lineage displaced other lineages in Great Britain to exceed $75 \%$ of the population in less than 3 years (Cooke et al. 2012). However, despite the dominance of a single or few clonal lineages, moderate to high genetic variation has been reported in northern and western Europe as a result of sexual recombination events resulting from the global migration of the A2 mating type from Mexico to Europe (Brurberg et al. 2011; Chmielarz et al. 2014). Although, in most regions of the world, the pathogen reproduces primarily in a clonal manner and sexual recombination events are rare (Gisi et al. 2011), the appearance of new genotypes through mutations such as transposable events and other genetic mechanisms led to high genetic diversity and phenotypic variation (Zhu et al. 2015). The appearance of new genotypes and the constant change in the genetic frequencies of these genotypes within $P$. infestans populations have shown the importance of continuously monitoring the population genetics of this pathogen. In Ecuador, SSR markers have been used to study the genetic diversity of $P$. infestans that was collected from potato crops (Delgado et al. 2013). Although a single clonal lineage (EC-1) dominated in the population, a high subclonal genetic diversity was reported in potato crops using SSR and phenotypic characterization (Delgado et al. 2013; Forbes et al. 1997; Oyarzún et al. 1998).

In the Andean regions of South America, control strategies against the late blight disease have been based on protective and systemic fungicides, and the use of resistant cultivars has been essentially scarce (Erwin and Ribeiro 1996). In these regions, the climatic conditions favor the development of epidemics that are difficult to control (Jaramillo 2003). Some efforts have been conducted to understand the population structure of $P$. infestans in Colombia. Previous studies on the populations of $P$. infestans in Colombia have focused on metalaxyl sensitivity tests and on the characterization of pathotypes (García et al. 2008; Jaramillo 2003). On the other hand, studies on population genetics support the hypothesis that the population of $P$. infestans in Colombia is homogeneous, consisting primarily of the EC-1 lineage (Cárdenas et al. 2012; Garnica et al. 2006; Mesa Salgado et al. 2008; Vargas et al. 2009). However, all of these previous studies have not incorporated the use of SSR markers to obtain a better resolution of the $P$. infestans population structure in Colombia. The last population study of the pathogen in Colombia was performed 9 years ago (Vargas et al. 2009). Therefore, in our study, the population genetic structure of a large set of $P$. infestans population isolates that were collected from potato fields ( $S$. tuberosum) was assessed with the aim to understand the population dynamics and the genetic variation of these isolates in the central region of Colombia, which is the country's primary production area. The clonal lineages of the isolates were assessed and 12 microsatellite loci (SSR) were used to genotype 279 P. infestans isolates collected from 11 geographic locations and 11 host cultivars. The tested hypotheses in this study were that (i) there exists a high genetic diversity within clonal lineages present in the central region of Colombia and (ii) the $P$. infestans isolates were genetically differentiated according to their geographic origin or the host genotype (cultivar). In addition, the study tested whether natural populations of $P$. infestans isolates that were collected in the central region of Colombia showed evidence of sexual reproduction.

\section{MATERIALS AND METHODS}

Collection and maintenance of $P$. infestans isolates. In total, 1,298 putatively infected leaves that exhibited symptoms akin to late potato blight were collected between July and December 2016 from potato crops (S. tuberosum Andigenum and Phureja Groups) in the central region of Colombia (Cundinamarca region) (Fig. 1; Supplementary Table S1). The host cultivars that corresponded to the Phureja Group were Criolla Colombia, Criolla Dorada, Criolla Ocarina, Milagros, and Paola; and the Andigenum Group cultivars were Diacol Capiro, Parda Pastusa, Superior, Pastusa Suprema, Tuquerreña, and ICA Unica. The Pastusa Suprema and Paola cultivars were considered resistant to late blight disease; the Milagros and ICA Unica cultivars were considered moderately resistant to late blight disease; and the Tuquerreña, Superior, Parda Pastusa, Diacol Capiro, Criolla Colombia, Criolla Ocarina, and Criolla Dorada were considered susceptible to late blight disease.

In total, 11 geographic localities were sampled, including the north $(\mathrm{N})$ of the central region, which included the localities of Tausa, Cogua, and Zipaquirá; the west (W) of the central region, which included Subachoque, El Rosal, Bojacá, and Mosquera; the central (C) part of the central region, which included Bogotá; and the northeast (NE) of the central region, which included Villapinzón, Chocontá, and Sesquilé (Fig. 1). The classification of regions as N, W, C, and NE was based on the characteristics of the agronomic and production systems of each locality.

Three to four leaves were sampled from 15 randomly selected plants that showed late blight symptoms from each field. Approximately $1 \mathrm{~cm}^{2}$ of infected leaf, between the necrotic and sporulating areas, was excised and placed in contact with a potato dextrose agar (PDA) medium that contained antibiotics (1 $\mathrm{ml}$ of rifampicin, $1 \mathrm{ml}$ of ampicillin, $1 \mathrm{ml}$ of chloramphenicol, and $1 \mathrm{ml}$ of pentachlonitrobenzene per liter) (Danies et al. 2013). In total, 278 isolates were successfully isolated and subsequently transferred again into a fresh PDA medium. All plates were grown at $18^{\circ} \mathrm{C}$ in the dark for 7 days and were stored in the Phytophthora collection at Universidad de los Andes (Bogotá, Colombia). Duplicates of all isolates collected in this study were stored in the Museum of Natural History at Universidad de los Andes.

In vitro mating type determination. To determine the mating type of the $P$. infestans isolates, in vitro mating-type tests were conducted for 279 strains of $P$. infestans. Mating-type tests were conducted by pairing each unknown isolate with a known isolate of $P$. infestans, either the A1 mating-type reference isolate (US970001, US-17 genotype) or the A2 mating-type reference isolate (US040009, US-8 genotype), in a medium that contained clarified rye, $10 \% \mathrm{~V} 8,1.5 \%$ agar, and $1 \mathrm{ml}$ of B-sitosterol per liter, which was adjusted to $\mathrm{pH} 8.5$ (Mayton et al. 2000). Petri dishes were kept at $18.5^{\circ} \mathrm{C}$ for 15 to 30 days. The hyphal interface of the two colonies was evaluated microscopically using $\times 125$ magnification. Isolates that formed oospores at the interface with the known A1 isolate were designated $\mathrm{A} 2$, and those that formed oospores with the known A2 isolate were designated A1. The known isolates (A1 and A2) were paired as positive controls, while negative controls consisted of the known isolates paired with themselves (same mating type) (Danies et al. 2014; Mayton et al. 2000). Two replicates were performed for each isolate.

Molecular characterization and population genetics. Agar plugs of each $P$. infestans isolate, which was obtained from the edge of a 7-day-old colony that had been actively growing on PDA, were transferred to plich broth (saccharose at $12.5 \mathrm{~g} \mathrm{liter}^{-1}$, yeast extract at $0.25 \mathrm{~g} \mathrm{liter}^{-1}$, B-sitosterol at $5 \mathrm{mg}^{-1}$ liter $^{-1}$, Lasparagine at $0.5 \mathrm{~g} \mathrm{liter}^{-1}$, and thymine at $5 \mathrm{ml} \mathrm{liter}^{-1}$ ). After 20 days of incubation, the mycelia were lyophilized, and the DNA was extracted using the DNeasy Plant Mini Kit (Qiagen), following the manufacturer's instructions. The DNA was suspended in TrisEDTA buffer ( $\mathrm{pH} 8.0)$ and was treated with RNAse. DNA quality 
and quantity were assessed using a NanoDrop ND-1000 (ThermoFisher). Finally, the DNA of each isolate was stored at $-80^{\circ} \mathrm{C}$ until needed.

The clonal lineage for the $P$. infestans isolates was determined via a restriction fragment length polymorphism (RFLP) analysis using the RG57 probe (Goodwin et al. 1992). Southern blot analysis was conducted using the Amersham gene images AlkPhos direct labeling and detection system (GE Healthcare) according to the manufacturer's instructions. The Netherlands isolate NL13316, US-17 genotype (US970001); the US-8 genotype (US400994); and the US-1 genotype (SA960008) were used as reference isolates in RG57 analyses. The presence or absence of known fingerprint fragments was scored visually.

All isolates were genotyped using a set of 12 polymorphic SSR markers (Cooke et al. 2012; Goss et al. 2014, Knapova and Gisi 2002; Lees et al. 2006; Li et al. 2013). The set of microsatellite markers used included D13, G11, PI04, Pi4B, Pi63, Pi70, PinfSSR2, PinfSSR3, PinfSSR4, PinfSSR6, PinfSSR8, and PinfSSR11 (Li et al. 2013) (Supplementary Tables S2 and S3). The polymerase chain reaction (PCR) conditions were as follows: $95^{\circ} \mathrm{C}$ for $5 \mathrm{~min}$; followed by 30 cycles of $95^{\circ} \mathrm{C}$ for $30 \mathrm{~s}, 58^{\circ} \mathrm{C}$ for $90 \mathrm{~s}$, and $72^{\circ} \mathrm{C}$ for $20 \mathrm{~s}$; and a final extension at $60^{\circ} \mathrm{C}$ for $30 \mathrm{~min}$. The PCR products were analyzed on an ABI 3730xl capillary system with POP-7 Polymer (ABI, PN 4335615). PCR amplicons were compared with a set of size standards, and alleles were scored accordingly (Danies et al. 2014; Li et al. 2013). Reference $P$. infestans isolates belonging to the US-8 (isolates US0400094 and US498095) and US-17 (isolate US970001) clonal lineages were included in all microsatellite analyses (Danies et al. 2014).

Considering that the reproduction of $P$. infestans isolates is typically clonal, population genetic analysis and population structure analyses were based on a Multilocus Genotype Analysis implemented on the Poppr package, version 2.5.0, available in the R Software (Kamvar et al. 2014). For each isolate, one specific multilocus genotype (MLG) was assigned according to the default parameters that were implemented on the Poppr package. Furthermore, clone correction was implemented to eliminate the redundancy in the collection as a result of clonal reproduction, using the "clonecorrect" function of the Poppr package (Grünwald and Hoheisel 2006; Grünwald et al. 2003; Kumar et al. 1999; Milgroom 1996).

To detect recombination or clonality within populations, the index of association $\left(\mathrm{I}_{\mathrm{A}}\right)$ and the standardized index of association (rrd) were calculated for isolates according to the geographic localities and host cultivars (Brown et al. 1980). The null hypothesis of random association of alleles $\left(\mathrm{I}_{\mathrm{A}}=0\right)$ was tested by 999 permutations, and $P$ values were defined with the "ia" function implemented on the Poppr package.

All genotypic diversity measures were calculated for all $P$. infestans isolates according to the geographic locality and the host cultivar from which the isolates were collected. Genotypic diversity (Nei 1987), evenness, and the Shannon-Wiener index of diversity were calculated with and without correction for sample size (Chao and Shen 2003). Additionally, we compared the ratio of observed

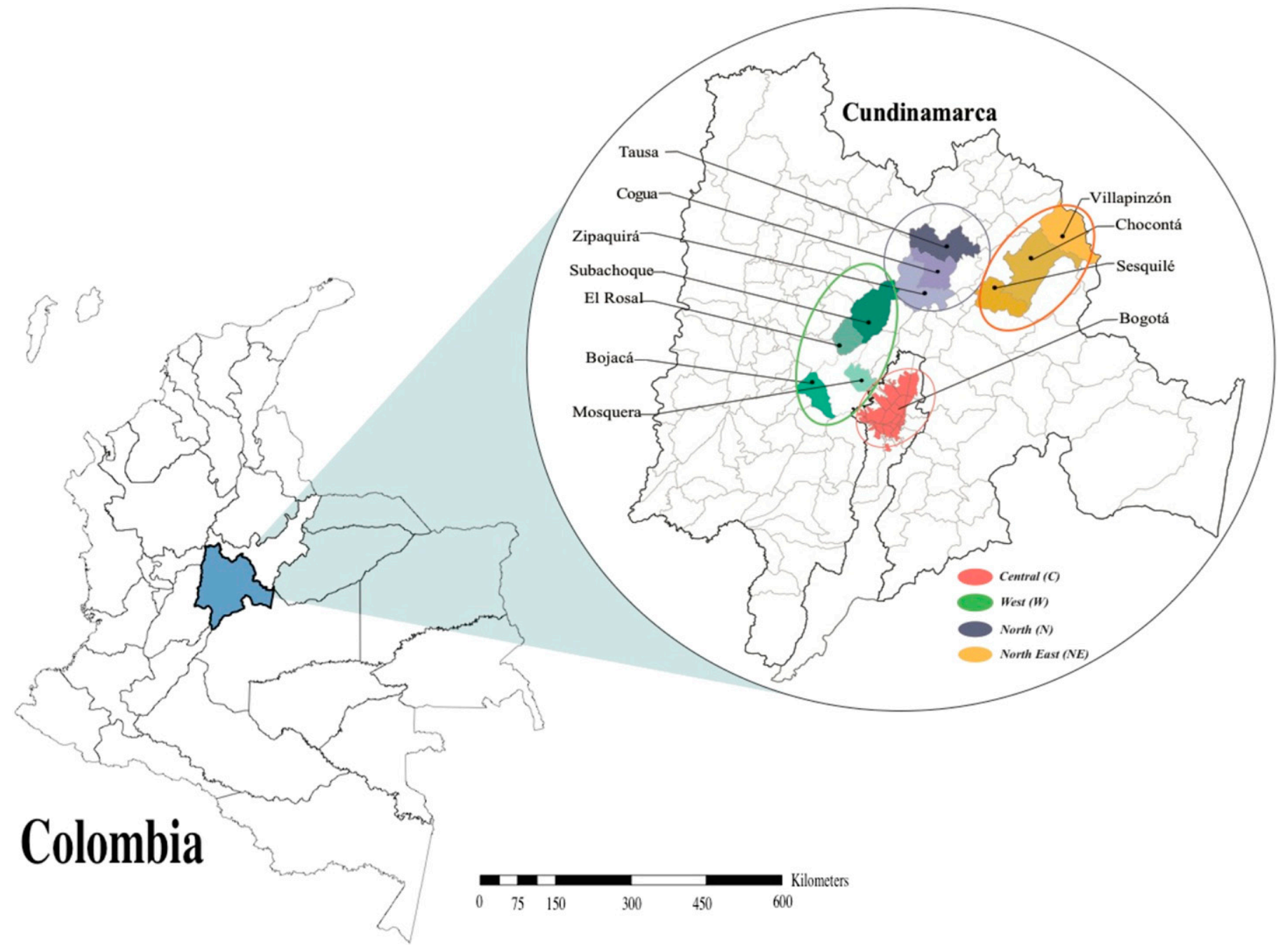

Fig. 1. Location of the area in central Colombia where the Phytophthora infestans isolates were collected. 
multilocus genotypic diversity to that expected under conditions of sexual reproduction, as described by Stoddart and Taylor (1988). All statistics were determined using the Poppr package (Kamvar et al. 2014). The $95 \%$ confidence intervals (CI) were calculated via the bootstrapping approach with 1,000 replicates for all genotypic diversity measures using the Poppr package.

To infer between-population relationships, microsatellite-based genetic distances were calculated using the Bruvo genetic distance (Bruvo et al. 2004). These genetic distances were then used to construct a minimum spanning genotype network using the Poppr package in the R software (Kamvar et al. 2014; R Core Team 2013).

To test the hypothesis that the $P$. infestans isolates were genetically differentiated according to the geographic locality or host cultivar, two-way analyses were conducted. First, we evaluated whether $P$. infestans isolates were structured according to the geographic localities and regions (N, W, C, and NE) and, second, we evaluated whether the $P$. infestans structure was defined by the potato cultivar.

Genetic differentiation between populations (geographic localities and cultivars) was calculated for the SSR genotypes using the $\mathrm{F}_{\mathrm{ST}}$ (Hartl and Clark 1997) that assumes the infinite alleles model. $\mathrm{F}_{\mathrm{ST}}$ was assessed using the GenAlEx v.6.5 software (Blynyon and Flanagan 2014; Peakall and Smouse 2012). The genetic differentiation criteria for $\mathrm{F}_{\mathrm{ST}}$ were as follows: 0 to 0.05 indicated little genetic differentiation, 0.05 to 0.15 indicated moderate differentiation, 0.15 to 0.25 indicated great differentiation, and values above 0.25 indicated very great genetic differentiation. The CI and significance of the $\mathrm{F}_{\mathrm{ST}}$ values were calculated via bootstrapping over loci (999 permutations, 95\% confidence level) (Grünwald et al. 2003). An analysis of molecular variance (AMOVA) (Excoffier et al. 1992) was also used to determine whether the genetic variance was partitioned between and within populations. AMOVA was performed using GenAlEx v.6.5 using the standard data setting and 999 permutations.

For comparison purposes, the contribution of individual alleles to the population structure among $P$. infestans populations was conducted over two additional analyses. First, a principal component analyses (PCA) was used to plot all individuals in the most significant axes space according to their genetic similarities; second, a discriminant analysis of principal components (DAPC) was conducted to extract information from genetic datasets (multivariate in nature) by first performing a (PCA) on predefined groups or populations and then using the PCA factors as variables for a discriminant analysis, which seeks to maximize the intergroup component of variation (Jombart et al. 2010). Both analyses were conducted using the adegenet package for R (Jombart 2008). The level of clustering on DAPC analysis was assessed with the function "find.clusters" run over two components. We used the Akaike Information Criterion to select the best supported model and, therefore, the number and nature of clusters.

Finally, a Mantel Test (Mantel 1967) was performed to test the correlation between genetic distance $\left(\theta_{\mathrm{ST}}\right)$ and geographic distance. These calculations were performed using the software GenAlEx v.6.5 (Blynyon and Flanagan 2014; Peakall and Smouse 2012).

TABLE 1. Number of total, unique, and shared multilocus genotypes (MLG) for Phytophthora infestans isolates according to their geographic origin

\begin{tabular}{|c|c|c|c|c|c|c|c|c|c|c|c|}
\hline \multirow[b]{2}{*}{ MLG, origin } & \multicolumn{11}{|c|}{ Locality, number of isolates, region ${ }^{\mathrm{a}}$} \\
\hline & $\begin{array}{c}\text { Bogotá } \\
(n=53) \mathrm{C}\end{array}$ & $\begin{array}{c}\text { Bojacá } \\
(n=17) \mathrm{W}\end{array}$ & $\begin{array}{l}\text { Chocontá } \\
(n=7) \mathrm{NE}\end{array}$ & $\begin{array}{c}\text { Cogua } \\
(n=3) \mathrm{N}\end{array}$ & $\begin{array}{l}\text { Mosquera } \\
(n=2) \mathrm{W}\end{array}$ & $\begin{array}{l}\text { El Rosal } \\
(n=2) \mathrm{W}\end{array}$ & $\begin{array}{c}\text { Sesquilé } \\
(n=45) \mathrm{NE}\end{array}$ & $\begin{array}{l}\text { Subachoque } \\
(n=53) \mathrm{W}\end{array}$ & $\begin{array}{c}\text { Tausa } \\
(n=24) \mathrm{N}\end{array}$ & $\begin{array}{l}\text { Villapinzón } \\
(n=55) \mathrm{NE}\end{array}$ & $\begin{array}{c}\text { Zipaquirá } \\
(n=18) \mathrm{N}\end{array}$ \\
\hline Total MLG & 21 & 11 & 7 & 3 & 1 & 2 & 18 & 25 & 7 & 20 & 11 \\
\hline Unique MLG & 14 & 4 & 1 & 1 & 0 & 0 & 7 & 16 & 1 & 9 & 3 \\
\hline Shared MLG & 7 & 7 & 6 & 2 & 1 & 2 & 11 & 9 & 6 & 11 & 8 \\
\hline Bogotá & $\ldots$ & $\ldots$ & $\ldots$ & $\ldots$ & $\ldots$ & $\ldots$ & $\ldots$ & $\ldots$ & $\ldots$ & $\ldots$ & $\ldots$ \\
\hline Bojacá & 5 & $\ldots$ & $\ldots$ & $\ldots$ & $\ldots$ & $\ldots$ & $\ldots$ & $\ldots$ & $\ldots$ & $\ldots$ & $\ldots$ \\
\hline Chocontá & 4 & 3 & $\ldots$ & $\ldots$ & $\ldots$ & $\ldots$ & $\ldots$ & $\ldots$ & $\ldots$ & $\ldots$ & $\ldots$ \\
\hline Cogua & 1 & 1 & 1 & $\ldots$ & $\ldots$ & $\ldots$ & $\ldots$ & $\ldots$ & $\ldots$ & $\ldots$ & $\ldots$ \\
\hline Mosquera & 1 & 1 & 1 & 1 & $\ldots$ & $\ldots$ & $\ldots$ & $\ldots$ & $\ldots$ & $\ldots$ & $\ldots$ \\
\hline El Rosal & 1 & 1 & 2 & 0 & 0 & $\ldots$ & $\ldots$ & $\ldots$ & $\ldots$ & $\ldots$ & $\ldots$ \\
\hline Sesquilé & 5 & 4 & 4 & 1 & 1 & 1 & $\ldots$ & $\ldots$ & $\ldots$ & $\ldots$ & $\ldots$ \\
\hline Subachoque & 3 & 3 & 3 & 2 & 1 & 1 & 6 & $\ldots$ & $\ldots$ & $\ldots$ & $\ldots$ \\
\hline Tausa & 3 & 3 & 3 & 1 & 1 & 1 & 4 & 5 & $\ldots$ & $\ldots$ & $\ldots$ \\
\hline Villapinzón & 4 & 4 & 3 & 1 & 1 & 1 & 8 & 6 & 5 & $\ldots$ & $\ldots$ \\
\hline Zipaquirá & 4 & 4 & 3 & 1 & 1 & 1 & 7 & 6 & 4 & 6 & $\ldots$ \\
\hline
\end{tabular}

a Regions for each locality are indicated as north $(\mathrm{N})$, west $(\mathrm{W})$, central $(\mathrm{C})$, and northeast (NE).

TABLE 2. Number of total, unique, and shared multilocus genotypes (MLG) for Phytophthora infestans isolates according to the host from which they were collected

\begin{tabular}{|c|c|c|c|c|c|c|c|c|c|c|c|}
\hline \multirow[b]{2}{*}{ MLG, cultivar } & \multicolumn{11}{|c|}{ Host cultivar and number of isolates } \\
\hline & $\begin{array}{c}\text { Criolla } \\
\text { Colombia } \\
(n=47)\end{array}$ & $\begin{array}{c}\text { Criolla } \\
\text { Dorada } \\
(n=22)\end{array}$ & $\begin{array}{c}\text { Criolla } \\
\text { Ocarina } \\
(n=9)\end{array}$ & $\begin{array}{c}\text { Diacol } \\
\text { Capiro } \\
(n=47)\end{array}$ & $\begin{array}{c}\text { Milagros } \\
(n=1)\end{array}$ & $\begin{array}{c}\text { Paola } \\
(n=8)\end{array}$ & $\begin{array}{c}\text { Parda } \\
\text { Pastusa } \\
(n=12)\end{array}$ & $\begin{array}{l}\text { Pastusa } \\
\text { Suprema } \\
(n=53)\end{array}$ & $\begin{array}{l}\text { Superior } \\
(n=62)\end{array}$ & $\begin{array}{l}\text { Tuquerreña } \\
\qquad(n=3)\end{array}$ & $\begin{array}{c}\text { ICA } \\
\text { Unica } \\
(n=15)\end{array}$ \\
\hline Total number of MLG & 21 & 14 & 3 & 22 & 1 & 8 & 10 & 26 & 26 & 3 & 8 \\
\hline Unique MLG & 10 & 5 & 0 & 7 & 0 & 1 & 1 & 11 & 13 & 1 & 1 \\
\hline Shared MLG & 11 & 9 & 3 & 15 & 1 & 7 & 9 & 15 & 13 & 2 & 7 \\
\hline Criolla Colombia & $\cdots$ & $\ldots$ & $\cdots$ & $\cdots$ & $\ldots$ & $\ldots$ & $\cdots$ & $\cdots$ & $\cdots$ & $\ldots$ & $\ldots$ \\
\hline Criolla Dorada & 5 & $\ldots$ & $\ldots$ & $\ldots$ & $\ldots$ & $\ldots$ & $\ldots$ & $\ldots$ & $\ldots$ & $\ldots$ & $\ldots$ \\
\hline Criolla Ocarina & 1 & 1 & $\ldots$ & $\ldots$ & $\ldots$ & $\ldots$ & $\ldots$ & $\ldots$ & $\ldots$ & $\ldots$ & $\ldots$ \\
\hline Diacol Capiro & 10 & 5 & 1 & $\cdots$ & $\ldots$ & $\ldots$ & $\ldots$ & $\cdots$ & $\ldots$ & $\ldots$ & $\ldots$ \\
\hline Milagros & 0 & 0 & 1 & 0 & $\ldots$ & $\ldots$ & $\ldots$ & $\ldots$ & $\ldots$ & $\ldots$ & $\ldots$ \\
\hline Paola & 2 & 4 & 1 & 4 & 0 & $\ldots$ & $\ldots$ & $\ldots$ & $\ldots$ & $\ldots$ & $\ldots$ \\
\hline Parda Pastusa & 4 & 4 & 3 & 6 & 1 & 3 & $\ldots$ & $\ldots$ & $\ldots$ & $\ldots$ & $\ldots$ \\
\hline Pastusa Suprema & 9 & 6 & 1 & 10 & 0 & 3 & 4 & $\ldots$ & $\ldots$ & $\ldots$ & $\ldots$ \\
\hline Superior & 9 & 6 & 2 & 10 & 0 & 4 & 6 & 9 & $\ldots$ & $\ldots$ & $\ldots$ \\
\hline Tuquerreña & 1 & 1 & 0 & 1 & 0 & 0 & 0 & 2 & 1 & $\ldots$ & $\ldots$ \\
\hline ICA Unica & 4 & 2 & 1 & 4 & 0 & 3 & 3 & 5 & 5 & 0 & $\ldots$ \\
\hline
\end{tabular}


For all analyses, only populations with more than 10 samples were considered.

\section{RESULTS}

Collection of $\boldsymbol{P}$. infestans isolates in the central region of Colombia. In total, $279 P$. infestans strains that were associated with late blight disease in Colombian potato fields were successfully isolated. The number of isolates according to the geographic location was Bogotá $(n=53)$, Chocontá $(n=7)$, Villapinzón $(n=55)$, Sesquilé $(n=45)$, Tausa $(n=24)$, Cogua $(n=$ $3)$, Zipaquirá $(n=18)$, Subachoque $(n=53)$, El Rosal $(n=2)$, Bojacá $(n=17)$, and Mosquera $(n=2)$, while the number of strains by host cultivar was Criolla Colombia $(n=47)$, Criolla Dorada $(n=22)$,

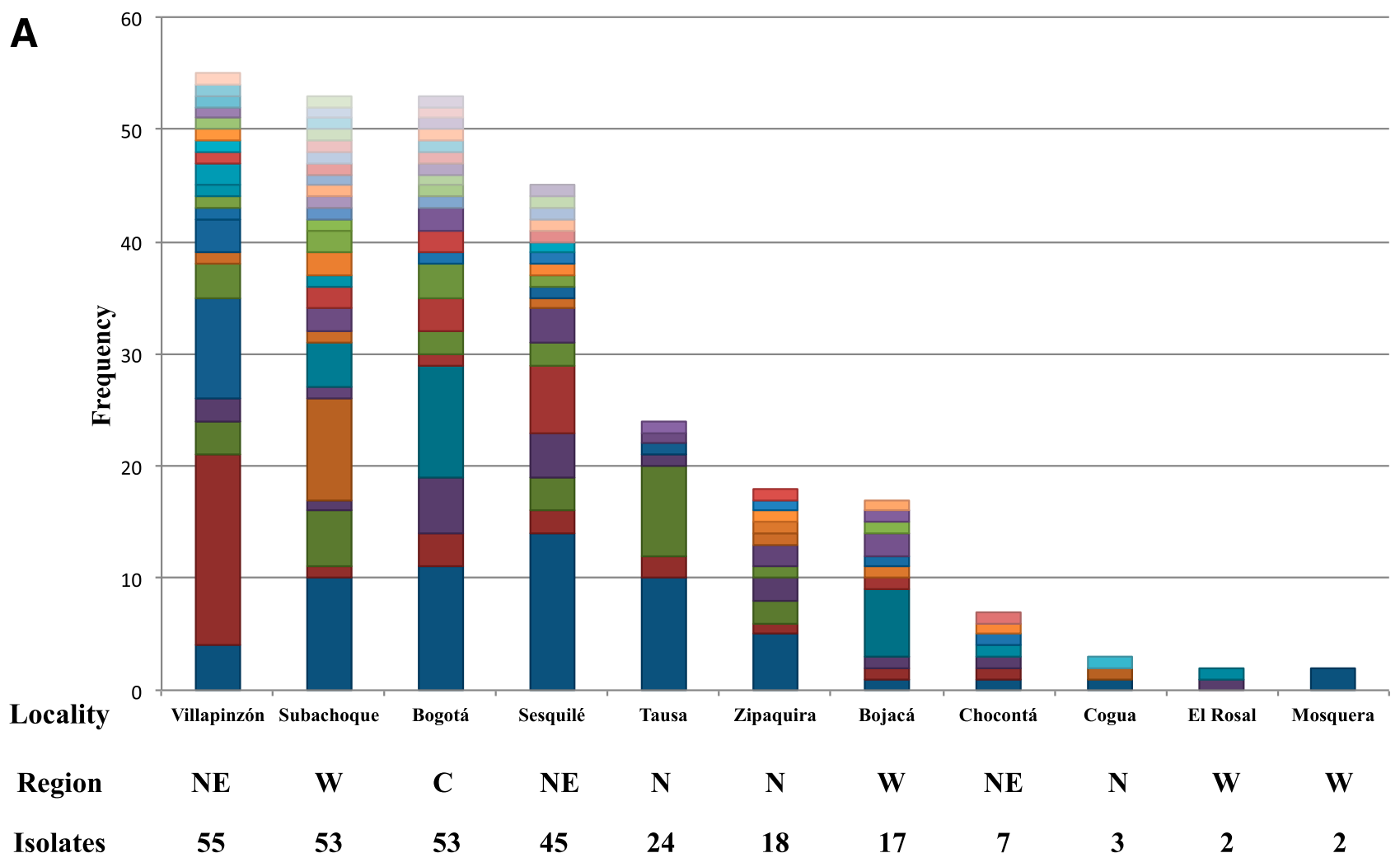

B

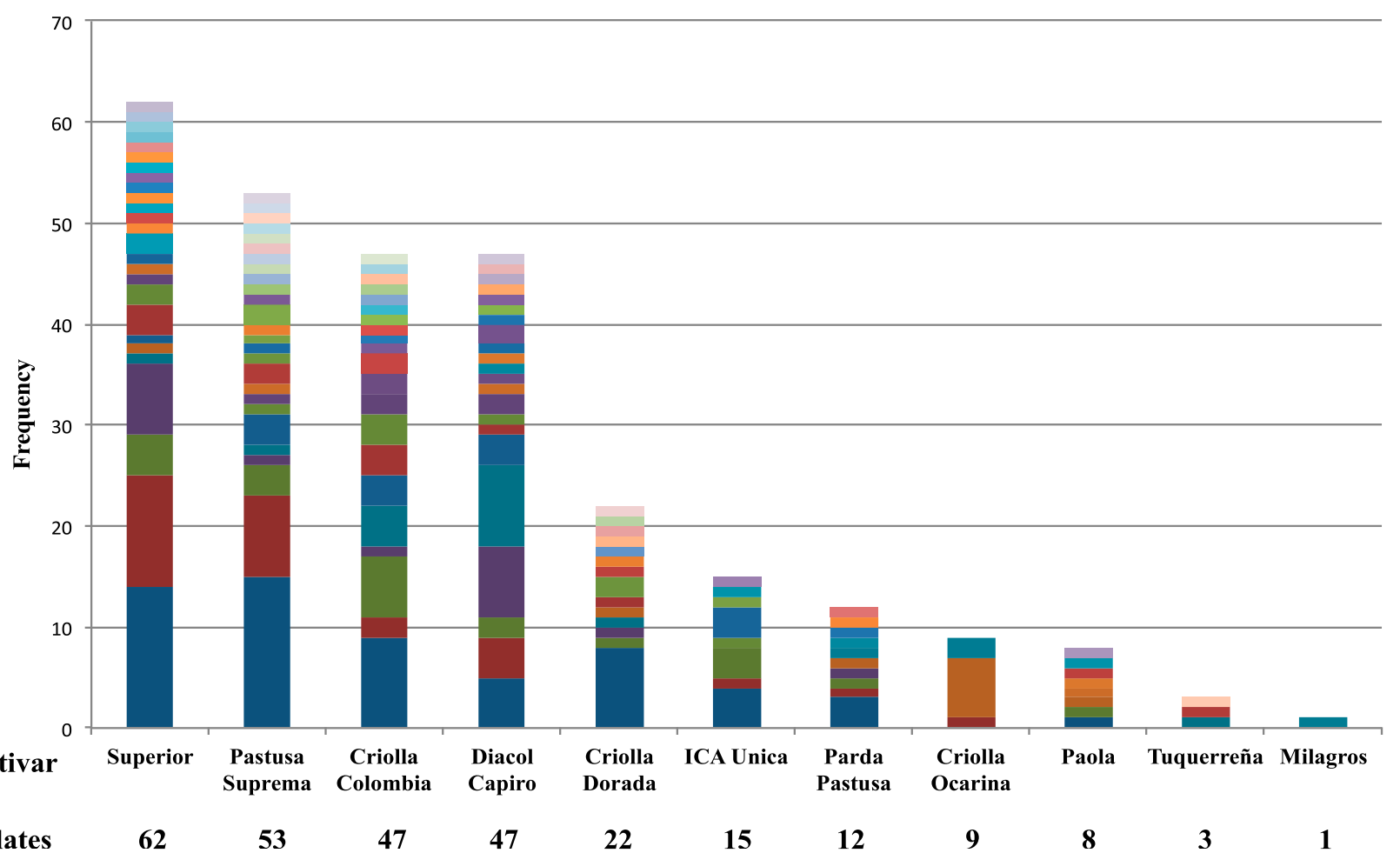

Fig. 2. Frequency of multilocus genotypes $\mathbf{A}$, in the 11 localities sampled (NE, W, C, and $\mathrm{N}=$ northeast, west, central, and north, respectively) and $\mathbf{B}$, on the 11 potato cultivars. Numbers of isolates fingerprinted in each locality or cultivar (11 geographic localities and 11 host cultivars) are indicated. 
Criolla Ocarina ( $n=9)$, Diacol Capiro $(n=47)$, Milagros $(n=1)$, Paola $(n=8)$, Parda Pastusa $(n=12)$, Superior $(n=62)$, Pastusa Suprema $(n=$ $53)$, Tuquerreña $(n=3)$, and ICA Unica $(n=15)$ (Tables 1 and 2).

Genetic diversity of $P$. infestans isolates in central Colombia. All P. infestans isolates were classified as clonal lineage EC-1. No polymorphic sites for the RFLP assay were detected, and a unique RFLP fingerprint was determined via RG57.

Twelve microsatellite loci were used to genotype the 279 $P$. infestans strains included in this study. In total, 55 alleles were obtained for the SSR used in this study. Among these, $13.11 \%$ were considered rare (frequency $<0.05$ ). The number of alleles per locus varied from 1 to 12 , with an average of 4.58 alleles per locus. The highest numbers of alleles were detected for the loci D13 (12 alleles), PinfSSR4 (9 alleles), PiG11 (6 alleles), and Pi4B (5 alleles). The locus Pi70 was completely monomorphic, and only one allele was reported in all samples. This last SSR marker was excluded from the analyses.

In total, 76 MLG were detected among all individuals for all of the microsatellites examined. A striking result is the high diversity of MLG detected in each population (11 cultivars and 11 localities in central Colombia) (Fig. 2). The most frequent MLG were MLG46, with a frequency of only $21.15 \%$, found in eight cultivars, 10 localities, and four regions; MLG44 (10.04\%), found in seven cultivars, 8 localities, and four regions; and MLG52 (7.53\%), found in eight cultivars, 4 localities, and three regions. In most of the regions, a high proportion of MLG was shared among localities (Table 1). Although Subachoque had a higher proportion of unique MLG (16 of 25 MLG), it shared genotypes with almost all of the other localities (Table 1). The localities of the $\mathrm{W}$ region did not behave similarly and, whereas Subachoque shared several MLG with localities in all regions, El Rosal, Cogua, and Mosquera shared few or no MLG with localities in other regions (Table 1). The unique and shared MLG per cultivar are shown in Table 2.

In all of the geographic localities, a high number of MLG were observed, and evenness values indicated that there were no dominant genotypes in any of the localities that were sampled. The maximum number of MLG was observed in Subachoque, which had 25 MLG (32.89\% of the 76 MLG obtained) (Tables 1 and 3 ). Among all localities, a higher genotypic richness was observed for Zipaquirá and Bogotá when equal sample sizes were considered (estimated as the number of expected MLG [eMLG]). The low number of eMLG compared with the number of MLG indicated that the same genotypes could be found in most of the localities (Table 3), as was shown previously (Tables 1 and 2). Genetic diversity ranged from 1.46 to 2.80 on the Shannon's information index $(\mathrm{H})$ and from 3.35 to 11.02 for the Stoddart and Taylor's diversity index. Bogotá and Subachoque were the localities that exhibited the highest values of genetic diversity, and Tausa showed the lowest values for genetic diversity (Table 3).

The minimum spanning network showed than there was not a dominant genotype per locality, but on the contrary, several genotypes were shared among several localities (Fig. 3). Based on genetic distance (Bruvo distance), a high similarity among MLG was observed. Only populations with more than 10 isolates were included in the analyses.

Similar analyses were conducted to unravel the genetic diversity of $P$. infestans isolates according to region $(\mathrm{N}, \mathrm{W}, \mathrm{C}$, and $\mathrm{NE}$ ) based on the characteristics of the agronomic and production systems of each locality. First, a dominant genotype could not be identified for

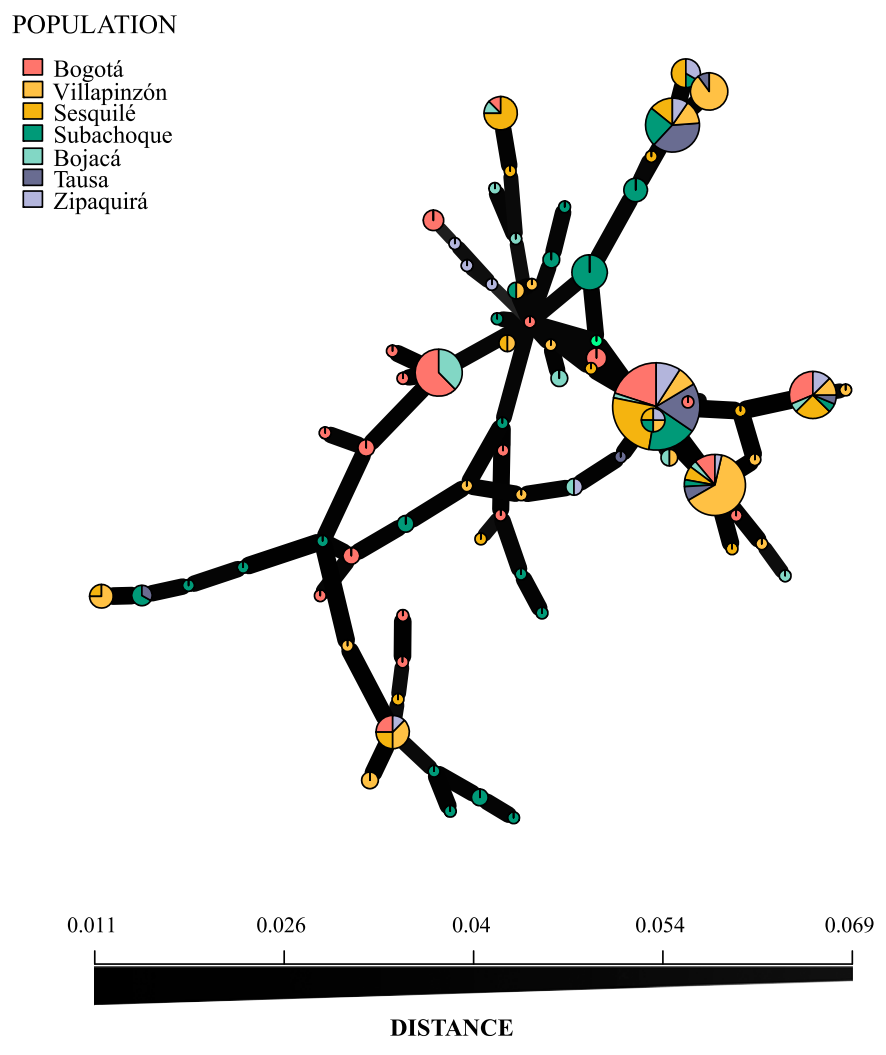

Fig. 3. Multilocus genotypes (MLG) network according to geographic locality based on Bruvo's genetic distance for microsatellite markers. Individual MLG are representing by nodes (circles). Edges (lines) represent minimum genetic distance between individuals. Only populations with more than 10 samples are included.

TABLE 4. Genetic diversity of the Phytophthora infestans isolates according to the region ${ }^{\mathrm{a}}$

\begin{tabular}{lrcccrcc}
\hline Region & \multicolumn{1}{c}{$N$} & MLG & eMLG & H & \multicolumn{1}{c}{ G } & E & Hexp \\
\hline Central & 53 & 21 & 19.1 & 2.62 & 9.46 & 0.663 & 0.470 \\
West & 74 & 34 & 24.4 & 3.10 & 14.34 & 0.629 & 0.411 \\
Northeast & 107 & 33 & 19.6 & 2.87 & 10.91 & 0.598 & 0.389 \\
North & 45 & 16 & 16.0 & 2.13 & 5.21 & 0.566 & 0.389 \\
Total & 279 & 76 & 23.1 & 3.372 & 13.36 & 0.439 & 0.399 \\
\hline
\end{tabular}

${ }^{a}$ Results were obtained from the simple-sequence repeat analysis using the Poppr package.

TABLE 3. Genetic diversity of Phytophthora infestans isolates according to geographic localities ${ }^{\mathrm{a}}$

\begin{tabular}{lllccccccc}
\hline Geographic regions & Localities & $N$ & MLG & eMLG & H & G & E & Hexp & rrd \\
\hline Northeast & Sesquilé & 45 & 18 & 6.76 & 2.42 & 7.11 & 0.599 & 0.399 & 0.54 \\
& Villapinzón & 55 & 20 & 6.63 & 2.44 & 6.99 & 0.571 & 0.381 & 0.016 \\
Central & Bogotá & 53 & 21 & 7.21 & 2.62 & 9.46 & 0.663 & 0.407 & 0.096 \\
North & Tausa & 24 & 7 & 4.33 & 1.47 & 3.35 & 0.703 & 0.371 & -0.017 \\
& Zipaquirá & 18 & 11 & 7.33 & 2.21 & 7.36 & 0.782 & 0.415 & 0.43 \\
West & Subachoque & 53 & 25 & 7.60 & 2.80 & 11.02 & 0.647 & 0.404 & 0.040 \\
& Bojacá & 17 & 11 & 7.14 & 2.12 & 5.90 & 0.669 & 0.441 & 0.186 \\
\hline
\end{tabular}

${ }^{a}$ Results were obtained from the simple-sequence repeat analysis using the Poppr package. $N=$ number of isolates, MLG $=$ number of multilocus genotypes (MLG) observed, eMLG = number of expected MLG at the smallest sample size $\geq 10$ based on rarefaction, $\mathrm{H}=$ Shannon's Information Index, $\mathrm{G}=\mathrm{Stoddart}$ and Taylor's Diversity Index of MLG, E = evenness, Hexp = Nei's unbiased gene diversity, and $\check{\text { rd }}=$ the standardized index of association. Populations with low sample sizes $(n<10)$ were not considered for this analysis. 
any region on the minimum spanning network for the regions $\mathrm{N}, \mathrm{W}$, NE, and central east (CE) (Supplementary Fig. S1). The DAPC analysis shows some differentiation of some localities of the $\mathrm{W}$ region. Genetic diversity ranged from 2.13 to 3.10 on the $\mathrm{H}$ and from 5.21 to 14.34 for the Stoddart and Taylor's diversity index, respectively. The $\mathrm{W}$ and $\mathrm{NE}$ regions were the localities with the highest values of genetic diversity, and $\mathrm{N}$ region showed the lowest

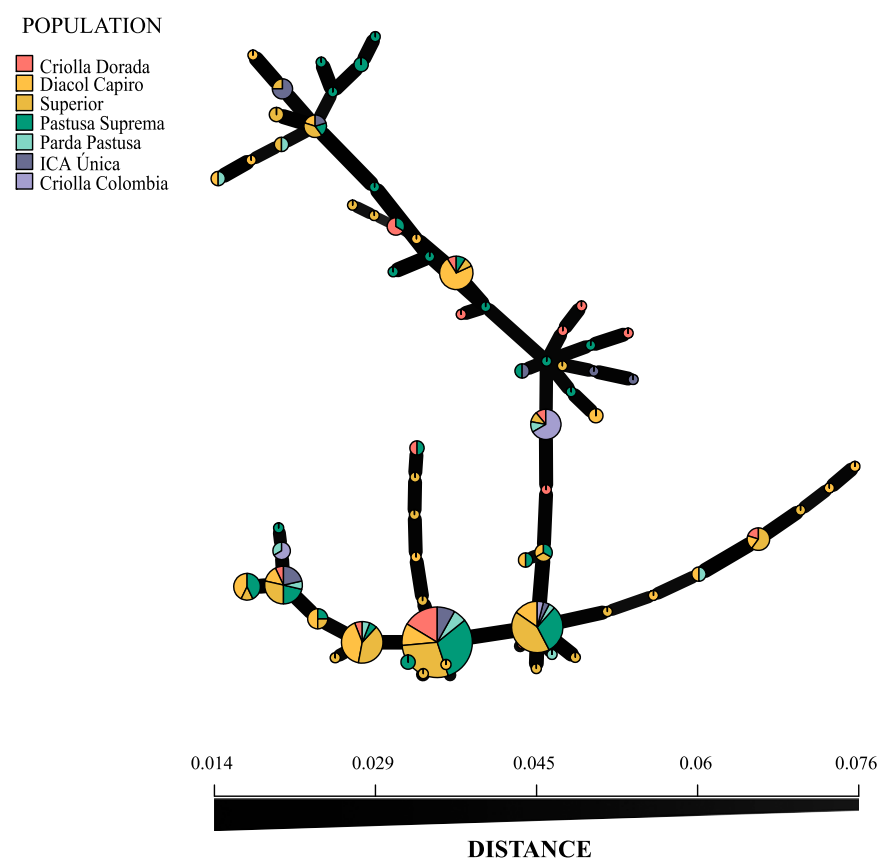

Fig. 4. Multilocus genotypes (MLG) network according to host cultivars based on Bruvo's genetic distance for microsatellite markers. Individual MLG are representing by nodes (circles). Edges (lines) represent minimum genetic distance between individuals. Only populations with more than 10 samples are included.

TABLE 5. Genetic diversity of the Phytophthora infestans isolates according to the host cultivar ${ }^{\text {a }}$

\begin{tabular}{lccccrcc}
\hline Host cultivar & $N$ & MLG & eMLG & H & \multicolumn{1}{c}{ G } & E & Hexp \\
\hline Criolla Colombia & 47 & 21 & 7.76 & 2.75 & 11.81 & 0.735 & 0.411 \\
Criolla Dorada & 22 & 14 & 7.17 & 2.27 & 6.05 & 0.581 & 0.420 \\
Diacol Capiro & 47 & 22 & 7.71 & 2.76 & 11.69 & 0.723 & 0.403 \\
Parda Pastusa & 12 & 10 & 8.50 & 2.21 & 8.00 & 0.862 & 0.401 \\
Pastusa suprema & 53 & 26 & 7.22 & 2.71 & 8.39 & 0.525 & 0.391 \\
Superior & 62 & 26 & 7.14 & 2.70 & 9.20 & 0.591 & 0.390 \\
ICA Unica & 15 & 8 & 6.29 & 1.90 & 5.77 & 0.840 & 0.392 \\
\hline
\end{tabular}

a Results were obtained from the simple-sequence repeat analysis using the Poppr package. $N=$ number of isolates, $\mathrm{MLG}=$ number of multilocus genotypes (MLG) observed, eMLG = number of expected MLG at the smallest sample size $\geq 10$ based on rarefaction, $\mathrm{H}=$ Shannon's Information Index, G = Stoddart and Taylor's Diversity Index of MLG, E = evenness, and Hexp = Nei's unbiased gene diversity. Populations with low sample sizes $(n<10)$ were not considered for this analysis. values for genetic diversity (Table 4). CI for all genotypic diversity measures are shown in Supplementary Table S4.

Genetic diversity distribution of $P$. infestans isolates according to the host cultivar. Similar results were detected for the host cultivars from which a high number of MLG were detected and no dominant genotypes were observed in any host genotype (Fig. 4). Diacol Capiro, Superior, Criolla Colombia, and Pastusa Suprema were the cultivars with the highest number of isolates collected and the highest number of MLG detected (26, 22, and 21 MLG, respectively; $34.21,28.95$, and $27.63 \%$ of the 76 MLG obtained, respectively). They exhibited the highest genotypic richness when equal sample sizes were considered (eMLG values) (Table 5). Genetic diversity ranged from 1.90 to 2.76 on the $\mathrm{H}$ and from 5.77 to 11.81 on the Stoddart and Taylor's diversity index (Table 5). Cultivars Milagros, Tuquerreña, Criolla Ocarina, and Paola were excluded from the final analyses due to their small sample sizes.

Population genetic structure of $P$. infestans is not shaped by the geographic origin of the isolates or the host cultivar. The pairwise $\mathrm{F}_{\mathrm{ST}}$ values for genetic differentiation according to geographic locations varied from -0.005 to 0.285 (Supplementary Table S5). Overall, two population pairwise comparisons (Tausa $[\mathrm{N}]$ versus Bojacá [W] [0.285] and Tausa [N] versus Bogotá [CE] $[0.281])$ showed significant genetic differentiation $(P<0.05)$. Some of the lowest genetic differentiations were detected between Sesquilé [NE] versus Bogotá [CE] (0.083), Sesquilé [NE] versus Bojacá [W] (0.076), Sesquilé [NE] versus Subachoque [W] (0.076), and Bojacá [W] versus Bogotá [CE] (0.054). Interestingly, Subachoque (W region) showed great levels of differentiation with Bojacá, which is also located in the $\mathrm{W}$ region $\left(\mathrm{F}_{\mathrm{ST}}\right.$ values of 0.144 ; $P<0.01)$.

The pairwise $\mathrm{F}_{\mathrm{ST}}$ values for genetic differentiation according to cultivars varied from -0.036 to 0.124 (Supplementary Table S6). $\mathrm{F}_{\mathrm{ST}}$ values with the highest levels of differentiation were detected for Superior versus two other cultivars-Tuquerreña $\left(\mathrm{F}_{\mathrm{ST}}\right.$ value of $0.108)$ and ICA Unica $\left(\mathrm{F}_{\mathrm{ST}}\right.$ value of 0.124$)$ - showing a moderate level of differentiation with nonsignificant values. All other comparisons showed little genetic differentiation.

The AMOVA showed that the genetic variation among regions was explained by $2.32 \%$ of variation and by $5.51 \%$ of variation among localities within regions (Table 6). In total, $8.78 \%$ of the genetic variation was explained by variations attributed among host cultivars. Finally, most of the variation $(83.39 \%)$ was explained by variation among individuals within host cultivars (Table 6).

Finally, the isolation-by-distance (IBD) effect was assessed for the $P$. infestans isolates, based on the Mantel test analysis (Supplementary Table S7). The results did not indicate significant correlation between genetic differentiation and geographic distance within geographic populations. However, when the correlation was estimated for pairs of regions, the results indicated a significant correlation between the genetic differentiation and geographic distance of the $\mathrm{N}$ geographic region compared with the $\mathrm{W}, \mathrm{NE}$, and C localities $\left(r^{2}=0.354, P=0.010 ; r^{2}=0.034, P=0.010\right.$; and $r^{2}=$ $0.208, P=0.010$, respectively) and between the $\mathrm{W}$ and the other regions.

Absence of sexual reproduction was detected in $P$. infestans isolates. In vitro mating type analyses showed that all $P$. infestans

TABLE 6. Analysis of molecular variance for Phytophthora infestans isolates among and within regions, geographic localities, and host cultivars ${ }^{\mathrm{a}}$

\begin{tabular}{|c|c|c|c|c|c|c|}
\hline Among and within & df & SSD & MSD & Variance component & Total $(\%)$ & $P$ value \\
\hline Among regions & 3 & 4.866 & 16.221 & 0.01 & 2.32 & $<0.001$ \\
\hline Among localities within regions & 7 & 4.858 & 0.6940 & 0.02 & 5.51 & $<0.001$ \\
\hline Among host within localities & 26 & 11.177 & 0.4299 & 0.03 & 8.78 & $<0.001$ \\
\hline Within host (cultivar) & 242 & 59.255 & 0.2449 & 0.24 & 83.39 & $<0.001$ \\
\hline Total & 278 & 80.157 & 0.288 & 0.29 & 100 & $\ldots$ \\
\hline
\end{tabular}

a $\mathrm{SSD}=$ sum of squares differences and MSD = mean square deviation. 
isolates collected from the central region of Colombia were of the A1 mating type. All isolates that paired with the A2 mating type reference isolate (US040009) US-8 formed mature oospores. The lack of sexual reproduction was also detected based on the results for the linkage analysis among the markers. For both geographic origin and host cultivar, the hypothesis of no linkage among markers was rejected $(P<0.001)$ for the uncorrected and clone-corrected populations (Supplementary Fig. S2). The řd of corrected populations varied from -0.017 to 0.54 . Multilocus linkage disequilibrium (LD) $\left(\mathrm{I}_{\mathrm{A}}\right.$ and $\breve{\text { rdd }}$ ) was significantly greater than zero within each population according to the geographic location $(P<0.001)$. The isolates from Sesquilé exhibited the highest řd (0.54), while the isolates from Tausa exhibited the lowest r̆d (-0.017) (Table 3). Similar results were detected according to the host cultivar. Multilocus LD ( $\mathrm{I}_{\mathrm{A}}$ and $\check{\mathrm{r} d}$ ) was significantly greater than zero within each population according to host cultivar $(P<0.001)$ (data not shown).

\section{DISCUSSION}

In this study, the population structure of $P$. infestans isolates collected from potato crops in the central region of Colombia was analyzed 9 years after the last study was conducted (Vargas et al. 2009). This is the first study that uses SSR to determine the withinclonal-lineage diversity and the first that determines whether Colombian populations of $P$. infestans are differentiated by the host genotypes used. Our results indicate that neither geographic location nor the potato genotype significantly shaped the population structure of the $P$. infestans population in central Colombia. Despite the high diversity, similar to that in the Nordic European countries (Brurberg et al. 2011), almost every isolate was a distinct genotype, and no evidence of sexual recombination was found. The populations of central Colombia are composed of a high number of genotypes that exhibit a high similarity among themselves (based on the Bruvo distance).

The correlation between genetic and geographic distances was nonsignificant among the sampled geographic locations; however, a significant effect of IBD was evident when the locations were grouped by $\mathrm{N}, \mathrm{W}, \mathrm{C}$, and NE regions, with a differentiation of the $\mathrm{W}$ and $\mathrm{N}$ localities. These differentiated localities of the $\mathrm{W}$ and a locality of the $\mathrm{N}$ (Tausa) of the central regions of Colombia should have as-yet-unidentified geographic and environmental conditions that can act as a partial barrier to prevent the gene flow among $P$. infestans isolates from and to other regions.

Genetic data from most of the localities showed the absence of genetic differentiation of the pathogen. It is common for P. infestans that high levels of gene flow prevent local adaptations, and it is rare to find geographic differentiations. For example, Glais et al. (2014) studied populations of $P$. infestans from Jersey and assessed the populations from the coasts of Brittany and Normandy as probable sources of genetic flow. Their results showed the absence of genetic differentiation between Jersey and the closest French sites, which indicated that gene flow at that spatial scale prevented the local adaptation in Jersey. In the Nordic European countries, the absence of a geographic structure was shown (Brurberg et al. 2011). In other populations, a dominant clonal lineage is widely spread over large geographic ranges (Li et al. 2012; Tian et al. 2015).

The absence of genetic structure according to the host cultivar suggests a high level of migration or gene flow among different host cultivars. These results suggest that geographic and environmental differences could partially explain the genetic differentiation of $P$. infestans more than the host cultivar. In our study, $P$. infestans isolates were collected from different potato cultivars with different genetic backgrounds and different reported levels of resistance or susceptibility; however, the potato cultivars had been grown in the same fields. The results also showed that adaptation of the host genotypes does not shape the diversity distribution of the pathogen. One line of evidence shows the lack of adaptation to particular genotypes. A higher number of MLG was detected on cultivars that were released on different dates (i.e., very old and very recent cultivars). Indeed, Diacol Capiro (22 MLG) was deployed more than 45 years ago (released in 1968), Criolla Colombia (21 MLG) was released in 1995, Pastusa Suprema (26 MLG) was deployed in 2003, and Superior (26 MLG) was released in the central region only 3 years ago. Interestingly, for breeding programs, a high number of MLG were detected on Pastusa Suprema, a cultivar considered to be resistant.

Prior to this study, low levels of genetic diversity were detected among $P$. infestans isolates from potato crops in Colombia. In previous studies, the EC- 1 clonal lineage was considered the dominant lineage among $P$. infestans isolates collected from potato in Colombia (Vargas et al. 2009). Studies based on other molecular markers such as amplified fragment length polymorphism markers (Mesa Salgado et al. 2008) have been consistent with clonal population structure. However, the use of microsatellite loci can produce additional polymorphisms to further differentiate $P$. infestans isolates from the same clonal lineage. The high mutational rate of microsatellite markers (Balloux and LugonMoulin 2002; Hamblin et al. 2007) supports the levels of diversity found in this study: 76 MLG were detected in only one region of Colombia, and very high levels of diversity were observed. The possibility of differentiating strains among clonal lineages is important for assessing the dynamics of the $P$. infestans population at fine geographic scales.

Finally, no evidence of sexual reproduction was detected for $P$. infestans isolates collected from potato crops in the central region of Colombia. The lack of sexual reproduction was detected based on the results for the no-linkage analysis among the markers, and the in vitro mating test showed that all isolates were classified as A1 mating type, consistent with an asexual population. In Colombia, only one isolate of the A2 mating type, which was collected in cape gooseberry (Physalis peruviana), was reported (Vargas et al. 2009). Therefore, the low frequency of the A2 mating type described in Colombia diminishes the chances for the occurrence of sexual reproduction (Cárdenas et al. 2011; Vargas et al. 2009). The A 2 mating type has been reported in Perú and Ecuador, and new allele combinations or strong genetic diversity is expected as a result of the sexual reproduction of the pathogen (Ordoñez et al. 2000).

All of these results provide important insights regarding the population structure and dynamics of Phytophthora infestans isolates in the central (and most productive) region of potato production in Colombia. For the first time, the subclonal variation was thoroughly described in the most important potato production region in Colombia, including the number of MLG and their geographic distribution. It was also shown that the populations were not structured according to the localities, with a gene flow among them. Additionally, the results could have a significant impact on designing new strategies to control the disease in Colombia and to deploy new potato genotypes. The highest number of MLG from the pathogen was collected in a potato cultivar that was released as resistant. The next step should be to evaluate the aggressiveness components of the MLG and use them in the future before deploying new cultivars.

\section{LITERATURE CITED}

Adler, N. E., Chacón, G., Flier, W. G., and Forbes, G. A. 2002. The Andean fruit crop, pear melon (Solanum muricatum) is a common host for A1 and A2 strains of Phytophthora infestans in Ecuador. Plant Pathol. 51:802.

Adler, N. E., Erselius, L. J., Chacon, M. G., Flier, W. G., and Ordonez, M. E. 2004. Genetic diversity of Phytophthora infestans sensu lato in Ecuador provides new insight into the origin of this important plant pathogen. Phytopathology 94:154-162.

Balloux, F., and Lugon-Moulin, L. 2002. The estimation of population differentiation with microsatellite markers. Mol. Ecol. 11:155-165.

Blynyon, M. D. J., and Flanagan, N. S. 2014. A comprehensive guide to: GenAlEx Genetic Analysis in Excel 6.5. Online publication. Nicotine Tob. 
Res. 16. https://academic.oup.com/ntr/article-abstract/16/Suppl_2/NP/ 1043575?redirectedFrom $=$ fulltext

Brown, A. H. D., Feldman, M. W., and Nevo, E. 1980. Multilocus structure of natural populations of Hordeum spontaneum. Genetics 96:523-536.

Brurberg, M. B., Elameen, A., Le, V. H., Naerstad, R., Hermansen, A., Lehtinen, A., Hannukkala, A., Nielsen, B., Hansen, J., Andersson, B., and Yuen, J. 2011. Genetic analysis of Phytophthora infestans populations in the Nordic European countries reveals high genetic variability. Fungal Biol. 115:335-342.

Bruvo, R., Michiels, N. K., D'Souza, T. G., and Schulenburg, H. 2004. A simple method for the calculation of microsatellite genotype distances irrespective of ploidy level. Mol. Ecol. 13:2101-2106.

Cárdenas, M., Danies, G., Tabima, J., Bernal, A., and Restrepo, S. 2012. Phytophthora infestans population structure: A worldwide scale. Acta Biol. Colomb. 17:227-240.

Cárdenas, M., Grajales, A., Sierra, R., Rojas, A., González-Almario, A., Vargas, A., Marín, M., Fermín, G., Lagos, L. E., and Grünwald, N. J. 2011. Genetic diversity of Phytophthora infestans in the Northern Andean region. BMC Genet. 12:23.

Chao, A., and Shen, T. J. 2003. Nonparametric estimation of Shannon's index of diversity when there are unseen species in sample. Environ. Ecol. Stat. 10:429-443

Chmielarz, M., Sobkowiak, S., Dębski, K., Cooke, D. E. L., Brurberg, M. B., and Śliwka, J. 2014. Diversity of Phytophthora infestans from Poland. Plant Pathol. 63:203-211.

Cooke, D. E. L., Cano, L. M., Raffaele, S., Bain, R. A., Cooke, L. R., Etherington, G. J., Deahl, K. L., Farrer, R. A., Gilroy, E. M., Goss, E. M., Grünwald, N. J., Hein, I., MacLean, D., McNicol, J. W., Randall, E., Oliva, R. F., Pel, M. A., Shaw, D. S., Squires, J. N., Taylor, M. C., Vleeshouwers, V. G. A. A., Birch, P. R. J., Lees, A. K., and Kamoun, S. 2012. Genome analyses of an aggressive and invasive lineage of the Irish potato famine pathogen. PLoS Pathog. 8:e1002940.

Danies, G., Myers, K., Mideros, M., Restrepo, S., Martin, F., Cooke, D., Smart, C., Ristaino, J., Seaman, J., Gugino, B., Grünwald, N., and Fry, W. E. 2014. An ephemeral sexual population of Phytophthora infestans in the Northeastern United States and Canada. PLoS One 9:e116354.

Danies, G., Small, I. M., Myers, K., Childers, R., and Fry, W. E. 2013. Phenotypic characterization of recent clonal lineages of Phytophthora infestans in the United States. Plant Dis. 97:873-881.

Delgado, R., Monteros-Altamirano, A., Li, Y., Visser, R. G. V., Van der Lee, T. A. J., and Vosman, B. 2013. Large subclonal variation in Phytophthora infestans populations associated with Ecuadorian potato landraces. Plant Pathol. 62:1081-1088.

Drenth, A., Tas, I. C. Q., and Govers, F. 1994. DNA fingerprinting uncovers a new sexually reproducing population of Phytophthora infestans in the Netherlands. Eur. J. Plant Pathol. 100:97-107.

Erwin, D. C., and Ribeiro, O. K. 1996. Phytophthora Diseases Worldwide. The American Phytopathological Society, St. Paul, MN.

Excoffier, L., Smouse, P. E., and Quattro, J. M. 1992. Analysis of molecular variance inferred from metric distances among DNA haplotypes: Application to human mitochondrial DNA restriction data. Genetics 131: 479-491.

Forbes, G. A., Escobar, X. C., Ayala, C. C., Revelo, J., Ordoñez, M. E., Fry, B. A., Doucett, K., and Fry, W. E. 1997. Population genetic structure of Phytophthora infestans in Ecuador. Phytopathology 87:375-380.

Forbes, G. A., Ristaino, J., Oliva, R. F., and Flier, W. 2011. A rebuttal to the letter to the editor concerning: Defining species boundaries in the genus Phytophthora: The case of Phytophthora andina. Plant Pathol. 61:221-223.

Fry, W. E. 2008. Phytophthora infestans: The plant (and $R$ gene) destroyer. Mol. Plant Pathol. 9:385-402.

Fry, W. E., Drenth, A., Spielman, L. J., Mantel, B. T., Davidse, L. C., and Goodwin, S. B. 1991. Population genetic structure of Phytophthora infestans in the Netherlands. Phytopathology 81:1330-1336.

García, H. G., Marin, M., Jaramillo, S., and Cotes, J. M. 2008. Sensitivity to four systemic fungicides of Colombian isolates of Phytophthora infestans. Agron. Colomb. 26:47-57

Garnica, D. P., Pinzón, A. M., Quesada-Ocampo, L. M., Bernal, A. J., Barreto, E., Grünwald, N. J., and Restrepo, S. 2006. Survey and analysis of microsatellites from transcript sequences in Phytophthora species: Frequency, distribution, and potential as markers for the genus. BMC Genomics 7:245.

Gisi, U., Walder, F., Resheat-Eini, Z., Edel, D., and Sierotzki, H. 2011. Changes of genotype, sensitivity and aggressiveness in Phytophthora infestans isolates collected in European countries in 1997, 2006 and 2007. J. Phytopathol. 159:223-232.

Glais, I., Montarry, J., Corbière, R., Pasco, C., Marquer, B., Magalon, H., and Andrivon, D. 2014. Long-distance gene flow outweighs a century of local selection and prevents local adaptation in the Irish famine pathogen Phytophthora infestans. Evol. Appl. 7:442-452.
Goodwin, S. B., Spielman, L. J., Matuszak, J. M., Bergeron, S. N., and Fry, W. E. 1992. Clonal diversity and genetic differentiation of Phytophthora infestans populations in northern and central Mexico. Phytopathology 82:955-961.

Goss, E. M., Tabima, J., Cooke, D., Restrepo, S., Fry, W. E., Forbes, G., Fieland, V., Cárdenas, M., and Grünwald, N. J. 2014. The Irish potato famine pathogen Phytophthora infestans originated in central Mexico rather than the Andes. Proc. Nat. Acad. Sci. USA 111:8791-8796.

Grünwald, N. J., and Flier, W. G. 2005. The biology of Phytophthora infestans at its center of origin. Annu. Rev. Phytopathol. 43:171-190.

Grünwald, N. J., Goodwin, S. B., Milgroom, M. G., and Fry, W. E. 2003. Analysis of genotypic diversity data for populations of microorganisms. Phytopathology 93:738-746.

Grünwald, N. J., and Hoheisel, G.-A. 2006. Hierarchical analysis of diversity, selfing, and genetic differentiation in populations of the oomycete Aphanomyces euteiches. Phytopathology 96:1134-1141.

Hamblin, M. T., Salas Fernandez, M. G., Tuinstra, M. R., Rooney, W. L., and Kresovic, S. 2007. Sequence variation at candidate loci in the starch metabolism pathway in sorghum: Prospects for linkage disequilibrium mapping. Crop Sci. 47:S-125-S-134.

Hartl, D., and Clark, A. 1997. Principles of Population Genetics, 3rd ed. Sinauer Associates, Sunderland, MA.

Haverkort, A. J., Boonekamp, P. M., Hutten, R., Jacobsen, E., Lotz, L. A. P., Kessel, G. J. T., Visser, R. G. F., and Vossen, E. A. G. 2008. Societal costs of late blight in potato and prospects of durable resistance through cisgenic modification. Potato Res. 51:47-57.

Hedrick, W. 1985. Book reviews: Genetics and conservation. Evolution 39: 1180-1181.

Jaramillo, S. 2003. Monografía sobre Phytophthora infestans (Mont.) de Bary. Universidad Nacional de Colombia, Medellín, Colombia.

Jombart, T. 2008. Adegenet: A R package for the multivariate analysis of genetic markers. Bioinformatics 24:1403-1405.

Jombart, T., Devillard, S., and Balloux, F. 2010. Discriminant analysis of principal components: A new method for the analysis of genetically structured populations. BMC Genet. 11:94.

Kamvar, Z. N., Tabima, J. F., and Grünwald, N. J. 2014. Poppr: An R package for genetic analysis of populations with clonal, partially clonal, and/or sexual reproduction. PeerJ 2:e281.

Knapova, G., and Gisi, U. 2002. Phenotypic and genotypic structure of Phytophthora infestans populations on potato and tomato in France and Switzerland. Plant Pathol. 51:641-653.

Kumar, J., Nelsen, R. J., and Zeigler, R. S. 1999. Population structure and dynamics of Magnaporthe grisea in the Indian Himalayas. Genetics 152: 971-984.

Lees, A. K., Cooke, D. E. L., Stewart, J. A., Sullivan, L., Williams, N. A., and Carnegie, S. F. 2009. Phytophthora infestans population changes: Implications. Pages 55-60 in: Proc. Eleventh EuroBlight Workshop, Hamar, Norway. PPO Spec. Rep. 13

Lees, A. K., Wattier, R., Shaw, D. S., Sullivan, L., Williams, N. A., and Cooke, D. E. L. 2006. Novel microsatellite markers for the analysis of Phytophthora infestans populations. Plant Pathol. 55:311-319.

Li, J., Browning, S., Mahal, S., Oelschlegel, A., and Weissmann, C. 2010. Darwinian evolution of prions in cell culture. Science 327:869-872.

Li, Y., Cooke, D. E., Jacobsen, E., and Van Der Lee, T. 2013. Efficient multiplex simple sequence repeat genotyping of the oomycete plant pathogen Phytophthora infestans. J. Microbiol. Methods 92:316-322.

Li, Y., van der Lee, T. A. J., Evenhuis, A., van den Bosch, G. B. M., van Bekkum, P. J., Förch, M. G., and Kessel, G. J. T. 2012. Population dynamics of Phytophthora infestans in the Netherlands reveals expansion and spread of dominant clonal lineages and virulence in sexual offspring. G3: Genes Genomes Genet. 2:1529-1540.

MacDonald, C. 2004. Molecular markers to study population structure and dynamics in beneficial insects (predators and parasitoids). Int. J. Pest Manage. 50:215-224.

Mantel, N. 1967. The detection of disease clustering and a generalized regression approach. Cancer Res. 27:209-220.

Mayton, H., Smart, C. D., Moravec, B. C., Mizubuti, E. S. G., Muldoon, A. E., and Fry, W. E. 2000. Oospore survival and pathogenicity of single oospore recombinant progeny from a cross involving US-17 and US-8 genotypes of Phytophthora infestans. Plant Dis. 84:1190-1196.

McDonald, B. A. 1997. The population genetics of fungi: Tools and techniques. Phytopathology 87:448-453.

McDonald, B. A., and Linde, C. 2002. Pathogen population genetics, evolutionary potential, and durable resistance. Annu. Rev. Phytopathol. 40:349-379.

Mesa Salgado, V. M., Mideros, M. F., Jaramillo-Villegas, S., Cotes-Torres, J. M., Lagos Mora, L. E., Pineda, R. P., and Marín, M. M. 2008. Variabilidad genética de aislamientos de Phytophthora infestans procedentes del suroeste de Colombia. Rev. Iberoam. Micol. 25:167-172.

Milgroom, A., Intrator, M., Madhavan, K., Mazzaro, L., Shandas, R., Lui, B., and Park, D. 2014. Mesoporous silica nanoparticles as a breast-cancer 
targeting ultrasound contrast agent. Colloids Surf. B Biointerfaces 116: 652-657.

Milgroom, M. G. 1996. Recombination and the multilocus structure of fungal populations. Annu. Rev. Phytopathol. 34:457-477.

Moges, A. D., Admassu, B., Belew, D., Yesuf, M., Njuguna, J., Kyalo, M., and Ghimire, S. R. 2016. Development of microsatellite markers and analysis of genetic diversity and population structure of Colletotrichum gloeosporioides from Ethiopia. PLoS One 11:e0151257.

Nei, M. 1987. Molecular Evolutionary Genetics. Columbia University Press, New York

Njambere, E. N., Vandemark, G., and Chen, W. 2010. Development and characterization of microsatellite markers of the fungal plant pathogen Sclerotinia trifoliorum. Genome 53:494-500.

Oliva, R. F., Kroon, L. P. N. M., Chacon, G., Flier, W. G., Ristaino, J. B., and Forbes, G. A. 2010. Phytophthora andina sp. nov., a newly identified heterothallic pathogen of solanaceous hosts in the Andean highlands. Plant Pathol. 59:613-625.

Ordoñez, M. E., Hohl, H. R., Velasco, A., Ramon, M. P., Oyarzun, P. J., Smart, C. D., Fry, W. E., Forbes, G. A., and Erselius, L. J. 2000. A novel population of Phytophthora, similar to P. infestans, attacks wild Solanum species in Ecuador. Phytopathology 90:197-202.

Oyarzún, P. J., Pozo, A., Ordoñez, M. E., Doucett, K., and Forbes, G. A. 1998. Host specificity of Phytophthora infestans on tomato and potato in Ecuador. Phytopathology 88:265-271.

Peakall, R., and Smouse, P. E. 2012. GenALEx 6.5: Genetic analysis in Excel. Population genetic software for teaching and research-an update. Bioinformatics 28:2537-2539.

R Core Team. 2013. R: A Language and Environment for Statistical Computing. Online publication. R Foundation for Statistical Computing, Vienna. http://www.R-project.org/

Seidl, M. F., and Thomma, B. P. H. J. 2014. Sex or no sex: Evolutionary adaptation occurs regardless. BioEssays 36:335-345
Simpson, M. C., Wilken, P. M., Coetzee, M. P., Wingfield, M. J., and Wingfield, B. D. 2013. Analysis of microsatellite markers in the genome of the plant pathogen Ceratocystis fimbriata. Fungal Biol. 117:545-555.

Stoddart, J. A., and Taylor, J. F. 1988. Genotypic diversity: Estimation and prediction in samples. Genetics 118:705-711.

Stukenbrock, E., and McDonald, B. A. 2009. Population genetics of fungal and oomycete effectors involved in gene-for-gene interactions. Mol. PlantMicrobe Interact. 22:371-380.

Tian, Y., Sun, J., Li, H., Wang, G., Ma, Y., Liu, D., Quan, J., and Shan, W. 2015. Dominance of a single clonal lineage in the Phytophthora infestans population from northern Shaanxi, China revealed by genetic and phenotypic diversity analysis. Plant Pathol. 64:200-206.

Vargas, A. M., Quesada, L. M., Céspedes, M. C., Carreño, N., González, A., Rojas, A., Paola, A. Z., Myers, K., Fry, W. E., Jiménez, P., Bernal, A. J., and Restrepo, S. 2009. Characterization of Phytophthora infestans populations in Colombia: First report of the A2 mating type. Phytopathology 99:82-88.

Visser, M. E. 2008. Keeping up with a warming world; assessing the rate of adaptation to climate change. Proc. R. Soc. B. 275:649-659.

Yoshida, K., Schuenemann, V. J., Cano, L. M., Pais, M., Mishra, B., Sharma, R., Lanz, C., Martin, F. N., Kamoun, S., Krause, J., Thines, M., Weigel, D., and Burbano, H. A. 2013. The rise and fall of the Phytophthora infestans lineage that triggered the Irish potato famine. eLife 2:e00731.

Zhan, J., Thrall, P. H., and Burdon, J. J. 2014. Achieving sustainable plant disease management through evolutionary principles. Trends Plant Sci. 19: 570-575.

Zhang, L., Wang, Q., Liu, Q., and Wang, Q. 2009. Sweetpotato in China. Pages 325-358 in: The Sweetpotato. G. Loebenstein and G. Thottappilly, eds. Springer, Dordrecht, The Netherlands.

Zhu, W., Yang, L. N., Wu, E. J., Qin, C. F., Shang, L. P., Wang, Z. H., and Zhan, J. 2015. Limited Sexual Reproduction and Quick Turnover in the Population Genetic Structure of Phytophthora infestans in Fujian, China. Sci. Rep. 5: Article 10094 